\title{
Intervertebral Disc Nucleus Repair: Hype or Hope?
}

\author{
Gauri Tendulkar, Tao Chen $₫$, Sabrina Ehnert, Hans-Peter Kaps and Andreas K Nüssler *(D)
}

Siegfried Weller Institute for Trauma Research at the BG Unfallklinik Tübingen, Eberhard Karls Universität Tübingen, Schnarrenbergstrasse 95, 72076 Tübingen, Germany

* Correspondence: andreas.nuessler@gmail.com; Tel.: +49-(0)7071-606-1065 (ext. 3064);

Fax: +49-(0)7071-606-1978

Received: 1 July 2019; Accepted: 20 July 2019; Published: 24 July 2019

\begin{abstract}
Chronic back pain is a common disability, which is often accredited to intervertebral disc degeneration. Gold standard interventions such as spinal fusion, which are mainly designed to mechanically seal the defect, frequently fail to restore the native biomechanics. Moreover, artificial implants have limited success as a repair strategy, as they do not alter the underlying disease and fail to promote tissue integration and subsequent native biomechanics. The reported high rates of spinal fusion and artificial disc implant failure have pushed intervertebral disc degeneration research in recent years towards repair strategies. Intervertebral disc repair utilizing principles of tissue engineering should theoretically be successful, overcoming the inadequacies of artificial implants. For instance, advances in the development of scaffolds aided with cells and growth factors have opened up new possibilities for repair strategies. However, none has reached the stage of clinical trials in humans. In this review, we describe the hitches encountered in the musculoskeletal field and summarize recent advances in designing tissue-engineered constructs for promoting nucleus pulposus repair. Additionally, the review focuses on the effect of biomaterial aided with cells and growth factors on achieving effective functional reparative potency, highlighting the ways to enhance the efficacy of these treatments.
\end{abstract}

Keywords: intervertebral disc; nucleus pulposus; scaffold; replacement; repair

\section{Introduction}

Degenerative disc disease (DDD) is a common clinical condition that causes chronic back pain [1]. Lower back pain is one of the leading causes of disability and thus places a high burden on healthcare systems worldwide; yet, it is not among the top 10disorders receiving research funding [2]. Clinical problems associated with intervertebral disc degeneration, including disc biology, disease pathophysiology, or biomechanics, have received close attention, which has enhanced the basic understanding of these issues [3-7]. Furthermore, advanced novel research mainly focuses on the fundamental topic of replacement and repair of the damaged tissue, which has accelerated its clinical translation [1,8-12]. The objective of this review is to highlight the need for therapeutic alternatives that allow repair with replacement of intervertebral discs (IVDs). Research that has focused on repair with replacement of the nucleus pulposus (NP) is discussed.

\section{IVD Degeneration}

IVDs are cartilaginous structures between the vertebral bodies that mainly provide flexibility and elasticity [13] and have a wide range of movement to the spine as a whole. In addition, IVDs strongly provide pressure and tensile resistance while transmitting mechanical load through the spinal column [14] and therefore support a variety of loads during daily activities. A healthy IVD is comprised of a proteoglycan-rich gelatinous center called the NP, which is peripherally enclosed by the 
collagen-rich annulus fibrosus (AF) and the cartilaginous endplate (CEP), which limit the peripheral rim of the disc superiorly and inferiorly [15]. The primary components of IVDs are water, cells (mainly chondrocyte-like cells and fibroblasts), proteoglycan, collagen, and other matrix components [16]. Fibrillar collagens, aggrecan, and water are the three main structural components of the IVD, all together contributing to around $90-95 \%$ of the volume of a healthy IVD [17], although their percentages vary across the disc [14].

Several etiological factors such as aging, smoking, infection, abnormal biomechanical loading, and nutrition insufficiency are thought to be involved in the pathogenesis of IVD degeneration $[17,18]$. Among these factors, genetic heritability is estimated to account for up to $74 \%$ [19]. As the degeneration process is highly correlated with aging, its pathologic changes occur starting from the second decade of life $[6,20]$. Substantial changes in biochemical composition and progressive loss of structural integrity are hallmarks of IVD degeneration [15] (as illustrated in Figure 1, where curved arrows define the transition from normal disc structure to later degenerative disc), which occurs mostly in adults aged over 30 years in one or more discs or during trauma and injury. Loss of proteoglycans and a decrease in the ratio of proteoglycan to collagen [17] consequently results in the loss of hydrostatic properties, which induces structural wear of the IVD [21] and thus progresses towards a fibrotic nature. Dehydration of NP and gradual disappearance of the NP-AF border contributes to the loss of normal architecture. Stress distribution over the NP tends to reduce at the center and accumulates more pressure around the periphery, effectively disabling the NP's load transfer function [22]. Due to a lack of intradiscal pressure, the load absorption and transmission in such dehydrated discs is significantly altered and subsequently, it results in disc-height reduction, osteophyte formation, facet joint arthritis, and deformation of vertebral bodies [23]. With continuing degeneration, the structural deficit is accompanied by leakage of the central NP material through cracks in the AF into the periphery. This results in immune cell activation, thereby evoking chronic back pain $[24,25]$. Since biochemical changes within IVDs have not yet been directly associated with chronic back pain, it is difficult to determine if the observed changes are due to aging or pathology [26].

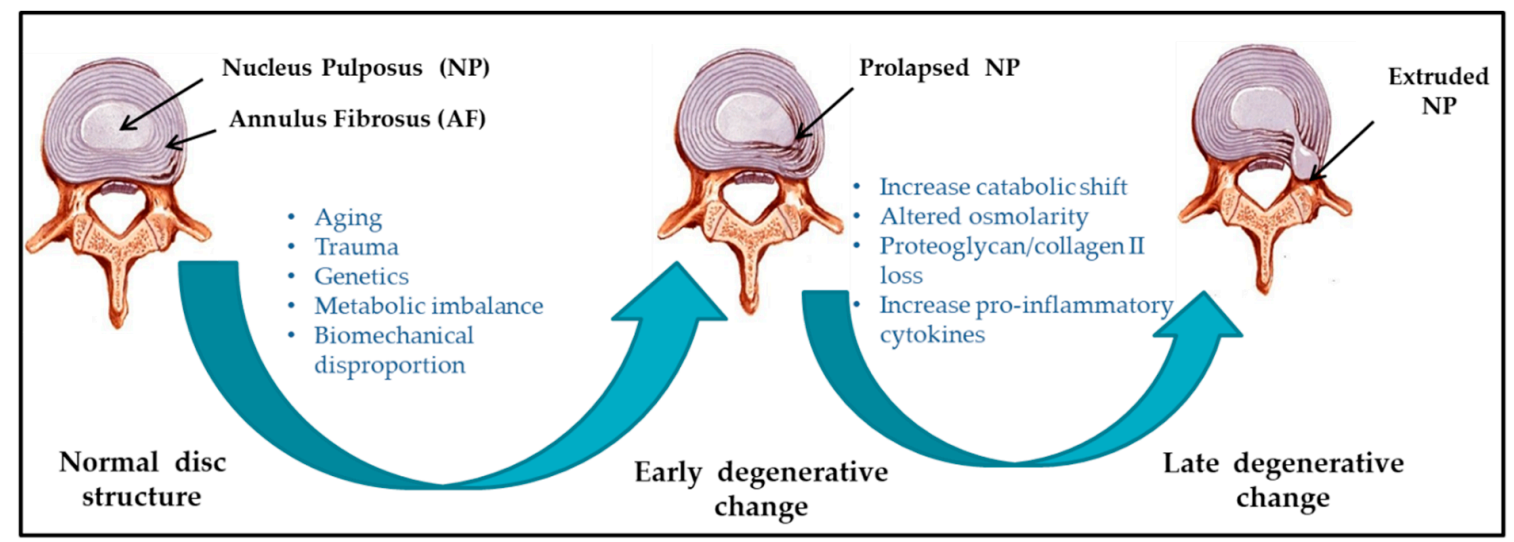

Figure 1. Schematic illustration of intervertebral disc (IVD) pathophysiology during degeneration.

IVD degeneration often results in lower back pain but is not always the only causative factor. Location of the affected disc, degree of nerve damage, and amount of pressure on the spinal column contribute to define the degree of degeneration. For example, some patients may not feel pain, while others with similar degrees and extents of IVD damage may experience chronic back pain. Therefore, the degree and extent of degeneration does not correlate with the degree of pain. IVD degeneration is the most common cause of lower back pain [27]. The worldwide prevalence of chronic back pain is approximate $60 \%$, with the majority seen in the elderly [28]. 


\section{NP Replacement}

Current surgical intervention aims to alleviate the symptoms instead of providing a complete cure [29-34]. Moreover, the avascular nature and low cellularity of IVDs often limit the regeneration potential [5,35-38]. A number of biomaterials/implants of good quality that can mimic NP tissue have been developed (refer Figure 2 ) and investigated in vitro and ex vivo $[39,40]$. NP replacement strategies administer a biocompatible material to retain the native biomechanics and to promote tissue integration $[10,41,42]$. In situ hydrating synthetic polymers (e.g., copolymeric hydrogel encased in a polyethylene fiber jacket polyacrylonitrile and polyacrylamide $\left(\mathrm{PDN}^{\mathrm{TM}}\right)$ ) for the NP approach have the longest history of clinical use. In situ forming synthetic polymers (e.g., chemically crosslinked biomaterial $\mathrm{NuCore}^{\mathrm{TM}}$, BioDisc ${ }^{\mathrm{TM}}$ ) represent another class for NP replacement. Controlling the degree of swelling remains one of the main advantages of synthetic polymers, which are otherwise used to mimic native disc properties [43]. However, excessive implant stiffness, endplate overloading and fracture, and fragmentation of gel upon swelling [44] are major drawbacks. Moreover, in vivo and clinical tests of mechanical repair have failed to promote tissue integration and restore the native biomechanics of the spine as a whole [10]. For these reasons, the use of biomaterials for NP repair has recently been approached with caution.

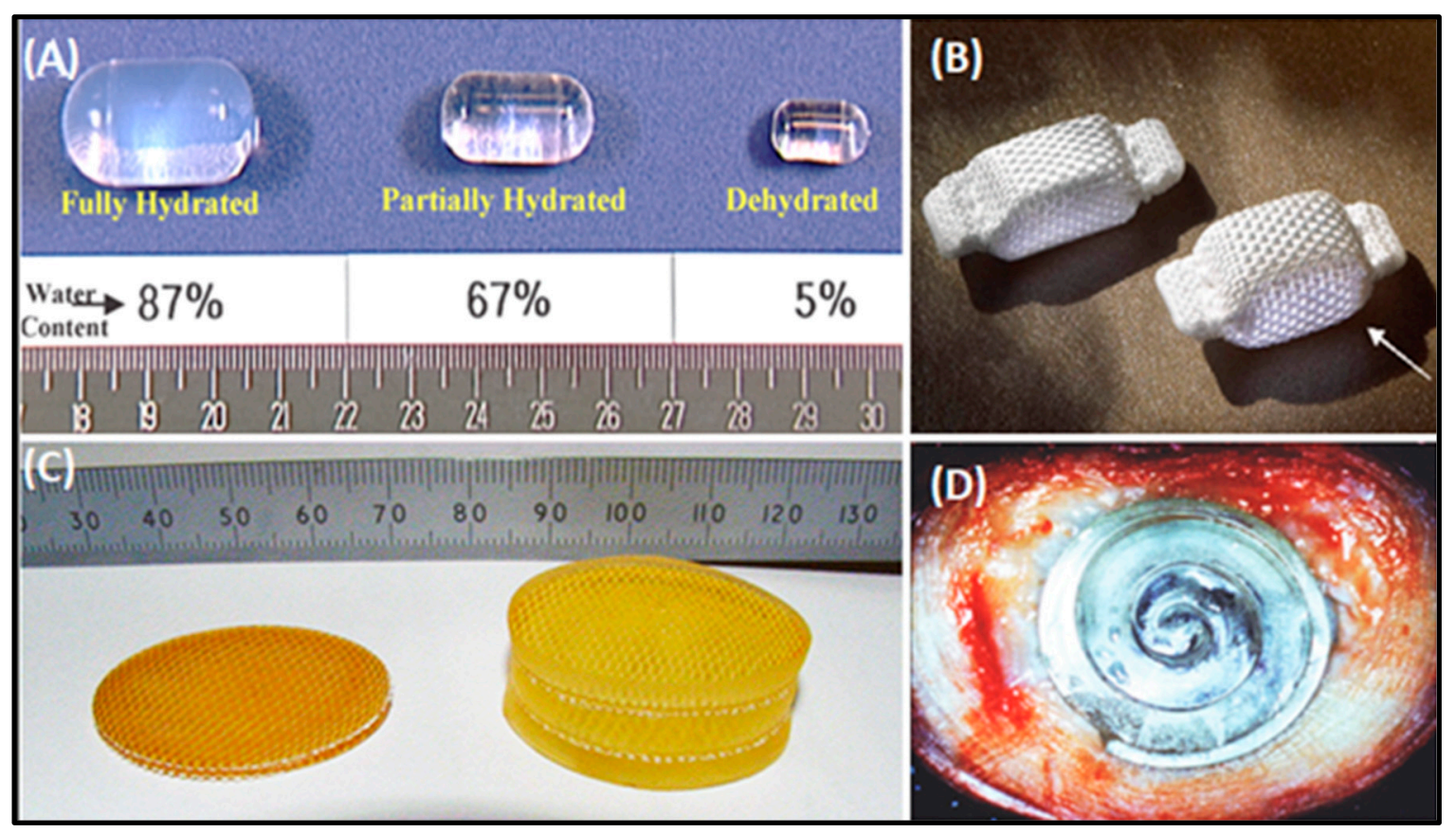

Figure 2. Nucleus replacement devices. (A) The Aquerelle poly (vinyl alcohol) hydrogel has a swelling pressure similar to the nucleus pulposus (NP) in vivo. Once implanted, its final volume depends on the water content at equilibrium (reprinted with permission from Stryker Spine, Allendale, NJ, USA). (B) The Prosthetic disc nucleus (PDN-SOLO) device in dehydrated (left) and hydrated (right; as indicated by arrow) states. This device was designed to swell both in height and width within the disc space. The porous polyethylene weave allows fluid to pass into the hydrophilic core, which causes the device to expand vertically and horizontally. This process maximizes the device's footprint on the vertebral endplates (reprinted with permission from Raymedica Inc., Minneapolis, MN, USA). (C) The Neudisc hydrogel, pre-hydration (left) and post-hydration (right). Hydration occurs in an anisotropic fashion, mainly in the vertical plane (reprinted with permission from Replication Medical, Inc., New Brunswick, NJ, USA). (D) The Newcleus Spiral Implant; once implanted, the device reconstitutes its original spiral shape. It localizes in place of the nucleus pulposus, which reconstitutes the volume, sparing the annular fibers (reprinted with permission from Zimmer Spine, Warsaw, IN, USA) [10,45]. 
NP injuries following annular injuries highlight the need for long-term stable repair strategies that yield native disc function through containment of the NP within the IVD and regeneration of native biomechanics. The exclusive focus on the mechanical repair of NP is the prime suspect of the failure of NP repair strategies [10]. In order to overcome the inadequacies of current mechanical implants of the nucleus pulposus, there is a definite need to enhance long-term regeneration to achieve persistent repair, thereby preventing further degeneration [46]. Utilizing the principle of tissue engineering, in combination with biomaterials, cells and/or growth factors potentially aim to regain the functional potency of intervertebral discs [28,47-50]. So far, common approaches for NP repair have involved the use of natural and synthetic biomaterials in combination with primary disc cells, stem cells, or growth factors [51]. Although the initial screening and characterization of novel repair strategies is valuable, it is critical for their continued progress to assess their safety and efficacy in vivo or ex vivo. In vivo models that mimic human IVD pathophysiology and biomechanics would be a gold standard for such assessments. In this review, we discuss biological NP repair strategies that have been or can be implemented in preclinical in vivo models and the remaining scientific challenges of successful NP repair.

\section{NP Repair}

Tissue engineering approaches over the past few years have been addressing the objective to restore functional and structural features of the healthy IVD. Reparative treatment mainly targets intervention at early stages of IVD degeneration to restore extracellular matrix (ECM) homeostasis, control inflammation, and prevent angiogenesis [2]. Current surgical procedures mainly focus on alleviating symptoms associated with IVD degeneration but fail to promote tissue remodeling. Tissue engineering offers an alternative to design biomaterials by encompassing cells and growth factors that will aid IVD tissue regeneration. Thereby, it offers multiple strategies to prevent and possibly cure IVD degeneration by encouraging disc repair. The exact mechanisms of IVD regeneration are still not known, however several studies have focused on the effect of segmental distraction in IVD disease [11,12,52]. Synthetic and / or natural material based scaffolds for IVD tissue engineering were regarded as the prominent method over the past decades [53,54]. In spite of considerable progress, some issues related to scaffold integration and tissue repair still remained unsolved [55]. Alternatively, scaffold free tissue engineering (refer Table 1) is an emerging field, where cells, growth factors, or peptide delivery are mainly responsible for regaining the tissue integrity upon the application $[56,57]$. Recently, stimulatory factors together with cells either unaided or together with biomaterials have aimed to provide suitable repair site to ensure maximum cell differentiation or deposition of appropriate ECM. Nonetheless, selection of biomaterials, cells and appropriate stimulatory factors is crucial as the ideal combination is yet to be established.

\section{Growth Factors}

Growth factors, such as bone morphogenetic proteins (BMPs), members of the transforming growth factor beta (TGF- $\beta$ ) super family, have shown an effective role in promoting cell proliferation in vitro as well as in vivo [11,58,59]. BMP2 treatment enhanced matrix production e.g., collagen II and aggrecan in rat, rabbit, and human IVD cells in vitro [60-62]. Interestingly, this effect was more distinct in adult rabbit IVD cells than in adolescent rabbit IVD cells [63]. In vivo (rabbit annular puncture model) intradiscal BMP2 injection did not impede progression of injury-induced degeneration as shown by Kong et al. [64]. In addition, Huang et al. showed BMP2 injection provoked acceleration of IVD degeneration and osteogenic responses near the vertebral endplates [65]. Regenerative effects of BMP2 on degenerated IVDs in vivo are thus controversial. BMP7 (osteogenic protein-1), another growth factor, is widely studied for NP regeneration. BMP7 had shown positive effects on ECM production [66-68]. An in vivo rabbit model showed disc height restoration and an increase in proteoglycan content upon recombinant human (rh) BMP-7 treatment [69,70]. Furthermore, in a rat IVD compression model its anti-catabolic effects were confirmed [71]. However, recently Willems 
et al. [72] and Van Dijk et al. [73] demonstrated that intradiscal application of rhBMP7 did not induce regeneration in a canine model of spontaneous intervertebral disc degeneration (IDD) and human derived NP tissue, respectively. Additionally, growth and differentiation factor 5 (GDF-5; also known as BMP-14) has shown positive impact on NP regeneration in vivo [74,75]. Thus, clinical trials of single intradiscal injection of rhGDF-5 and their resultant data with respect to adverse effect development and neurological status of patients have been published (http://clinicaltrials.gov/show/: NCT01182337; NCT01158924; NCT00813813; NCT01124006) [76]. Apart from this, a need for sustained delivery of TGF- $\beta$ during regeneration has been proposed from a mouse IVD compression model, where TGF- $\beta$ showed AF cell proliferation with increased gene expression of aggrecan and collagen II [77]. Moreover, insulin-like growth factor-1 (IGF-1) [78,79], basic fibroblast growth factor (bFGF) $[79,80]$, epidermal growth factor (EGF), and platelet derived growth factor (PDGF) [79], as well as platelet-rich plasma (PRP) [81] have been reported to enhance IVD cell proliferation and matrix synthesis. In vivo studies (rabbit model of IDD induced by annular puncture) on GDF-5 injection showed restorative effect on disc height with improved histologic and magnetic resonance imaging (MRI) (showing improved hydrophilic properties of NP) findings [74]. Also, synergistic effects of multiple growth factor cocktails can be considered as therapeutic approaches [82]. In parallel, the effects of growth factors on human degenerative discs deserve further investigations. Despite reasonable success achieved by growth factors, some important limitations such as dose, delivery, half-life, side effects etc. should be contemplated in the application of growth factor therapy. Moreover, the effects of single dosage/injections of growth factors are not sustainable over a longer period, while multiple dosages may cause inflammatory reactions. In addition, injections of TGF- $\beta$, IGF- 1 and bFGF may induce unwanted angiogenesis that may accelerate further deterioration [75]. It may therefore limit its clinical application. Nevertheless, further studies are required to confirm the safety and efficacy of intradiscal application [83]. Moreover, the injected growth factor does not distort the structural integrity and thus, biomechanical alteration even after the growth factor treatment may fail in clinical settings [84,85]. To overcome the demerits of growth factor delivery, gene therapy as an alternative strategy has been investigated to retard IDD. However, their effects and safety issues on human disc are not clear yet.

\section{Cell-Based Therapies}

Cell based therapy for IVD nucleus repair mainly aims for NP like cells injections, addressing the imbalance of biochemical environment (proteoglycan synthesis and water content). Stimulation of the residing cells is insufficient to achieve tissue repair; hence, diseased phenotype properties of the native NP cells certainly limit their use. Thus, injecting functional cells aimed to overcome this problem by compensating cell death and disc shrinkage $[51,86]$. Concomitantly, Abbott et al. proposed NP cells do possess regeneration potential even in severe status of degeneration [87]. Several cell-based strategies have been investigated to retard NP degeneration, using different IVD model system [88-91], with $\mathrm{NP}$ and/or AF cells, articular chondrocytes, or mesenchymal stem/stromal cells (MSCs). Feng et al. summarized GDF- 5 a suitable growth factor for inducing NP-like cells based on its positive effect on the differentiation of MSCs towards an NP-like phenotype [92]. The effect of growth factors such as TGF- $\beta$, IGF-1, FGF-2, PDGF and GDF- 5 on the differentiation of MSCs into NP-like cells have been investigated [92]. Fundamentally, the transplanted MSCs are expected to differentiate, maintain and enhance the function of existing NP cells to reverse the IDD. Thus, preclinical studies will be required to confirm the functional potency of the MSC-based therapy for IDD. In the Euro Disc study, percutaneous injection of autologous IVD cells demonstrated disc height restoration and pain reduction for up to two years following transplantation [93,94]. However a lack of placebo-controls is the drawback of the results. Similarly, in the NuQu phase I safety study percutaneous injections of allogeneic juvenile knee chondrocytes into degenerated lumbar IVDs of 15 human patients showed improved pain scores and radiological parameters within a period of 12 months of observation. Therefore, a phase II clinical trial regarding safety and efficacy of allogenic chondrocytes injection is ongoing [94]. Furthermore, several phase I and II studies with autologous and allogeneic MSCs are currently being performed 
(NCT01290367; NCT02037204; NCT02338271; NCT01860417) [94]. Good accessibility and the ability of MSCs (bone marrow, adipose and synovial tissue derived) to differentiate into different cell types including chondrocyte like cells, promoted MSCs as prime source for cell therapies for several diseases and in IVD regenerative treatment $[95,96]$. Intradiscal delivery of bone marrow and adipose derived MSCs has demonstrated to promote regeneration by maintaining cell viability and proliferation, obtaining IVD-like phenotypes, and providing expression of typical chondrocyte markers, in several studies using rabbit, rat, dog, and goat models [9,97-100]. Nevertheless, one common problem affecting the healing satisfaction is the tendency of hypertrophic differentiation of MSCs [101,102]. How to achieve an ideal IVD repair mainly relies on manipulation of hypertrophic chondrogenesis of the injected and/or implanted MSCs.

In parallel, the use of notochordal cells is also being considered, no matter from allogenic, autologous or xenogenic origin [103-105]. Risbud et al. has previously proposed that morphology and size variation correlates to different stages of maturation and/or function of NP cells derived from notochordal precursors [106]. Moreover, it has been speculated that degeneration is due to the selective loss of the notochordal cells fraction while considering overall reduction in the structural and functional activity of IVD cells. While there is considerable agreement, Bach et al. demonstrated the species (human, canine and porcine) specific regenerative effects of notochordal cell conditioned medium on human NP cells. It further confirmed the canine and porcine secreted factors exerted regenerative effect on human NP cells [107]. The fact that NP cells with diseased phenotype possess regeneration potential, allows autologous NP cells to be expanded using conditioned medium that these cells can be used as a source for cell therapy during nucleus repair. Likewise, stem cells can be differentiated towards NP like cell type. van Uden et al. has already addressed [48] the importance of hypoxia during NP repair. This key factor may restrict the success of the stem cell based therapy, as stem cells tend to die due to lack of oxygen. Serigano et al. demonstrated the effect of cell number on mesenchymal stem cell transplantation in canine disc degeneration model, where they showed high possibility of apoptosis, low cell viability, while maintaining microenvironment during stem cell transplantation [108]. Altogether, it affected the regeneration capability. However, in order to advance clinical translation of cell therapy, assessment of in vivo integration (in terms of functional and mechanical repair) in large animals is necessary. Therefore, a comparative analysis of cell types and sources of cells using large animal models is essential to enlighten the suitable strategy.

\section{Injectable Hydrogels}

Synthetic or biologically based injectable materials are largely focused on NP replacement, to stabilize and restore the function and structure of the discs and AF. Moreover, the biomaterial must satisfy the biomechanical strength with no migration and displacement, and durability with high wear resistance provoking low immune response. Injectable hydrogel over the solid-state scaffold opens up novel approaches in musculoskeletal application. Hydrogels mainly composed of natural polysaccharides (chitosan, chondroitin sulfate, hyaluronic acid), proteins (silk, resilin), or synthetic polymers (polyvinyl alcohol (PVA), polyacrylic acid, acrylamide), are emergent matrix substitutes in cartilage and IVD regeneration [109]. They are hydrophilic in nature, and have a water retention capacity between $20 \%$ and $99 \%$ by weight when placed in aqueous conditions. Therefore, these water soluble polymers are often used to build scaffolds by three-dimensional crosslinking either by covalent or physical methods. Hydrogels (depending on the physical structure and chemical composition) that mimic the mechanical stability and matrix composition of native IVD ECM, are a potential promising choice for IVD repair. Cell-free hydrogels and cell-seeded hydrogels are the two broad subtypes of injectable scaffolds found in literature $[110,111]$. 
Table 1. Advantages and disadvantages of scaffold-free IVD tissue engineering.

\begin{tabular}{|c|c|c|c|c|}
\hline Methods & Categories & Advantages & Disadvantages/Limitations & References \\
\hline \multirow[t]{2}{*}{$\begin{array}{l}\text { Cell } \\
\text { therapy }\end{array}$} & NP cells & $\begin{array}{l}\text { 1. No immune resistance } \\
\text { 2. Restricted to } \\
\text { chondrogenic lineage }\end{array}$ & $\begin{array}{ll}\text { 1. } & \text { Donor-site morbidity } \\
\text { 2. } & \text { Dedifferentiation issue } \\
\text { 3. } & \text { Low proliferation ability } \\
\text { 4. } & \text { Multiple surgical procedures }\end{array}$ & [88-91] \\
\hline & MSCs & $\begin{array}{ll}\text { 1. } & \text { Abundant cell resources } \\
\text { 2. } & \begin{array}{l}\text { High proliferation rate and } \\
\text { chondrogenic } \\
\text { differentiation capacity }\end{array} \\
\text { 3. Immunomodulatory abilities } \\
\text { 4. }\end{array}$ & $\begin{array}{ll}\text { 1. } & \begin{array}{l}\text { Not restricted to } \\
\text { chondrogenic lineage }\end{array} \\
\text { 2. } & \text { Potential disease transmission } \\
\text { 3. } & \text { Tumorigenesis risk }\end{array}$ & [94-102] \\
\hline \multirow{5}{*}{$\begin{array}{l}\text { Growth } \\
\text { factors }\end{array}$} & TGF- $\beta$ & $\begin{array}{l}\text { Enhances cartilage formation and } \\
\text { extracellular matrix production }\end{array}$ & $\begin{array}{l}\text { 1. No immediate structural and } \\
\text { biomechanical alteration } \\
\text { 2. Biodegradation in vivo }\end{array}$ & {$[58,77]$} \\
\hline & BMP2 & $\begin{array}{l}\text { Enhances ECM production and } \\
\text { phenotypic characteristics of NP cells }\end{array}$ & $\begin{array}{l}\text { Induces apoptosis, Col I } \\
\text { accumulation, and } \\
\text { aggrecan-production hindrance }\end{array}$ & [60-65] \\
\hline & BMP7 & $\begin{array}{l}\text { Promotes proliferation and accelerates } \\
\text { chondrogenesis }\end{array}$ & $\begin{array}{l}\text { Short half-life time and } \\
\text { biodegradation in vivo }\end{array}$ & [66-73] \\
\hline & GDF-5 & Induces NP-like differentiation of MSCs & $\begin{array}{l}\text { Possible association between GDF- } 5 \\
\text { gene polymorphisms and IDD }\end{array}$ & [74-76] \\
\hline & IGF-1 & $\begin{array}{l}\text { Enhances the ECM production and } \\
\text { proliferation of IVD cells }\end{array}$ & $\begin{array}{l}\text { Enhances glucose consumption and } \\
\text { lactate concentration }\end{array}$ & {$[78,79]$} \\
\hline \multirow[t]{2}{*}{$\begin{array}{l}\text { Injectable } \\
\text { hydrogel }\end{array}$} & $\begin{array}{l}\text { Cell-free } \\
\text { hydrogel }\end{array}$ & Physiological swelling and greasing & Limited payload & {$[51,110]$} \\
\hline & $\begin{array}{l}\text { Cell-seeded } \\
\text { hydrogel }\end{array}$ & $\begin{array}{l}\text { 1. Active matrix synthesis } \\
\text { 2. Preserves the behavior of } \\
\text { seeded cells }\end{array}$ & No direct cell contact & [111-114] \\
\hline
\end{tabular}

MSC: mesenchymal stem cell; BMP: bone morphogenetic protein; GDF: growth and differentiation factor; IGF: insulin-like growth factor; ECM: extracellular matrix; IDD: intervertebral disc degeneration.

Theoretically, biodegradability of some of the scaffolds allows remodeling of the scaffold in the regeneration process, while other scaffolds mechanically support and resist the compressive load for longer duration. For example, alginate and lyophilized chitosan gelatin scaffolds showed cytocompatibility towards the NP like cells, supporting cell growth. Li et al. stimulated NP cells using BMP-2 and BMP-7 heterodimer combined with fibrinhyaluronan hydrogel [112]. Their in vitro as well as ex vivo study demonstrated to produce aggrecan and collagen II by NP cells upon delivery, simulating in vivo conditions [112]. Moreover, cell numbers were found to be increased in alginate compare to lyophilized chitosan-gelatin based scaffolds, after 21 days of cell culture [51]. Hydrogels on the other hand resemble NP material, mainly due to their resilient and hydrophilic properties. Recently, several studies [91,110,111,113,114] have investigated the combination of cells and hydrogels to catalyze the tissue repair. Homogenous distribution of cells within defect size prior to gelation tends to support tissue repair [51]. To allow the sustainable effect of the growth factor Yan et al. administered the injection of poly (lactic-co-glycolic acid) (PLGA) microspheres loaded with recombinant human GDF-5 into a rat caudal disc degeneration model induced by needle puncture [115]. Sustained release of active GDF- 5 for more than 42 days confirmed its therapeutic efficacy. Further Frith et al. [114] conducted a study examining the composite of injectable hydrogels (polyethylene glycol, hyaluronic acid, and pentosanpolysulphate) coupled with MSCs. In vivo examination of this scaffold composite 
together MSCs in rats, certainly supported the cartilage like tissue formation, thereby confirming the deposition of collagen II. However, there is a need to identify relevant combination of biomolecules and hydrogel material that may direct NP cell survival in vivo, in the challenging mechanical and physical microenvironment of the NP. While doing so, the biomaterial should withstand the mechanical load which ultimately contribute to the longevity of the scaffold.

\section{Future Research Areas: Attempts to Regenerate the NP during Replacement}

The pathophysiology of the disc at different stages of degeneration is not well characterized yet. High complexity and heterogeneity of IVDs, mainly limits the understanding of IDD process. Therefore, NP repair requires comprehensive understanding of the degrees and the extents of IVD degeneration, followed by designing a scaffold with suitable structure and biological activity that will create conductive microenvironment for the biological interaction in vivo. Pre-requisite of the pivot joint (IVD) replacement often highlights the load-bearing factor, and therefore, mechanical replacement remains the conventional choice for severe degrees of IVD degeneration. However, IVD degeneration treatment highly demands for tissue repair aiming to generate functional neo-tissue formation (refer Figure 3, where red dotted arrows indicate the possible ways of tissue repair), while considering in vivo mechanical stimuli. Despite the fact that the biomechanical replacement offers a promising perspective for NP regeneration, comprehensive consideration of interdisciplinary strategies addressing biological and mechanical needs for NP repair certainly may achieve regeneration.

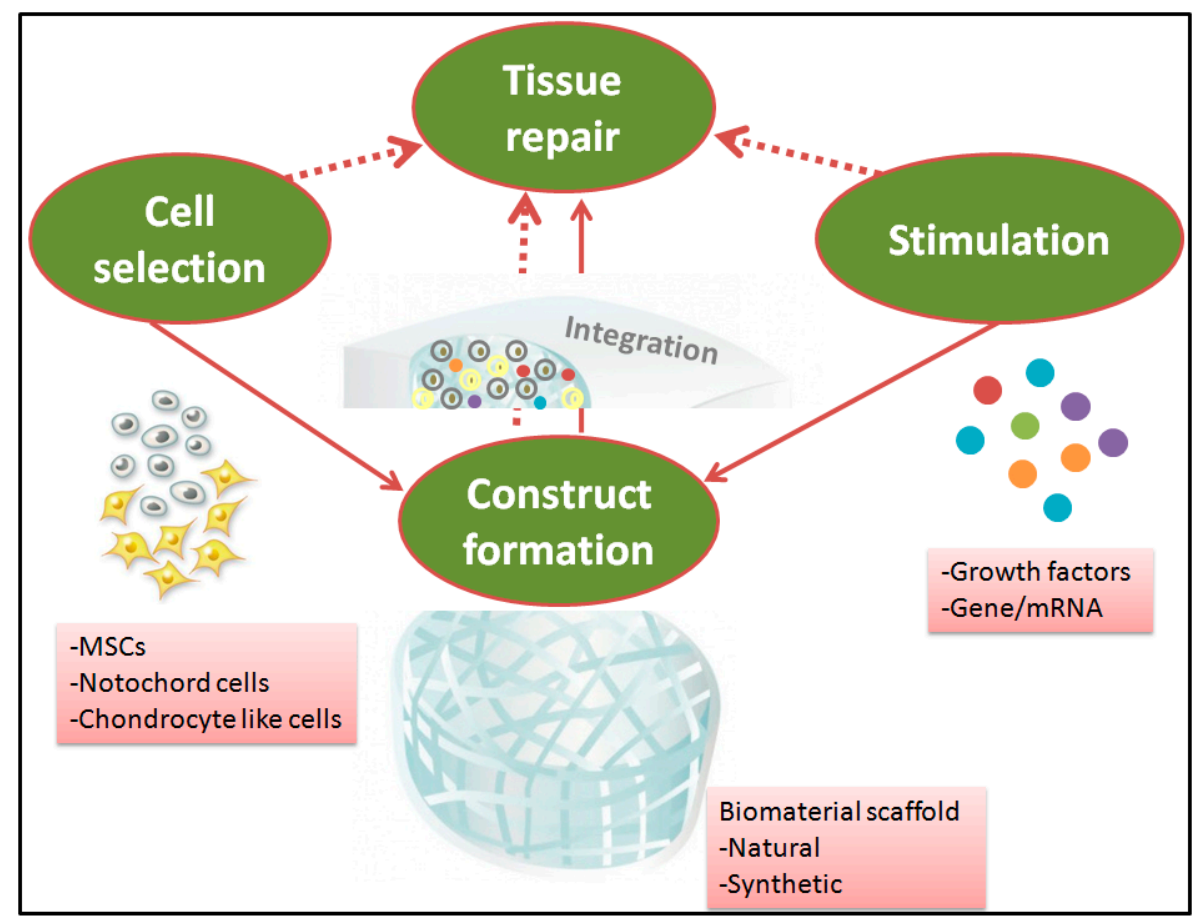

Figure 3. Synergetic tissue engineering strategies for nucleus pulposus repair.

Tissue engineering strategies therefore should be directed to use scaffolds, cells and bioactive stimuli all together, as a reparative approach (refer Figure 3, where red solid arrows indicate the possible ways of combination), allowing cellular interaction for load-bearing application-targeted scaffolds. The impact of mechanical loading on cell behavior is one of the major considerations in this type of strategy, as scaffold's long-term durability is expected not to cause further complication. Therefore, a precise material selection for NP repair that supports minimally invasive implantation, in situ fixation and defect filling are likely to have a higher success rate. In this scenario, an emergence of third generation biomaterials in the healthcare system is contributing to develop strategies of combining appropriate stimulatory factors/growth factors together with biomaterial and/or cells to enhance the 
endogenous regeneration potential $[1,86]$, thereby assuring a potential tissue repair. Although, tissue engineering and regenerative medicine strategies aim at catalyzing an efficient restoration of single tissues (AF or NP), their short term success and unclear long term biological consequences mainly limit their clinical application. Therefore, restoration of two dissimilar tissues, the AF and NP collectively should be in focus. Recently, Moriguchi et al. demonstrated a tissue engineered IVD-construct: AF cells seeded on a collagen based hydrogel and NP cells seeded on an alginate hydrogel were formed into a single disc unit using preformed canine spine geometry molds [116]. Histological analysis confirmed host tissue integration over 16 weeks without elevation of immune reaction. Such strategies will have to be dealt with developing a scaffold that leads to regeneration of NP-AF concurrently. With rapidly accumulating knowledge on the advanced drug delivery, cell therapy and stimulatory agents, a more robust approach exploring the diverse biomaterials may provide superior efficacy-targeting NP repair and thus, advanced IVD degeneration therapy may work successfully $[117,118]$. Importantly, the experimental outcome should intend to correlate with the final aim of chronic back pain relief in humans while considering the clinical translation.

\section{Conclusions}

In the past decade, biomaterials either unaided or together with cells/growth factors have gained significant attention in the field of IVD regeneration. Here, we discussed NP repair strategies, where injectable hydrogels, cell and growth factor based therapies have been extensively studied both in vitro and in vivo. However, the conflict of tissue integration and load-bearing capacity limits so far a long-term application of currently available and well-tested NP repair strategies. Emergence of third generation biomaterials in the health care system, aided together with cells and growth factors is still more a fiction than a fact. Yet, it is our hope that the tissue engineering based approaches for NP repair will stimulate further research to seek more satisfying solutions to be added into the biomedical pipeline.

Author Contributions: Conception, G.T. and A.KN.; Investigations, G.T. and T.C.; Writing-Original Draft Preparation, G.T. and T.C.; Writing-Review and Editing, A.KN., H.-P.K., and S.E.; Supervision, A.KN.

Funding: The study was partially supported by Zentrales Innovationsprogram Mittelstand (ZIM) des Bundesministeriums für Wirtschaft und Energie-KF3010902AJ4. We also acknowledge support by Deutsche Forschungsgemeinschaft and the Open Access Publishing Fund of the University of Tübingen.

Conflicts of Interest: The authors declare no conflict of interest.

\section{Abbreviations}

$\begin{array}{ll}\text { AF } & \text { annulus fibrosus } \\ \text { BMP } & \text { bone morphogenetic protein } \\ \text { CEP } & \text { cartilaginous endplate } \\ \text { DDD } & \text { degenerative disc disease } \\ \text { ECM } & \text { extracellular matrix } \\ \text { GDF } & \text { growth and differentiation factor } \\ \text { IVD } & \text { intervertebral disc } \\ \text { IDD } & \text { intervertebral disc degeneration } \\ \text { MMP } & \text { matrix metalloproteinase } \\ \text { MSC } & \text { mesenchymal stem cells } \\ \text { NP } & \text { nucleus pulposus }\end{array}$

\section{References}

1. Clouet, J.; Fusellier, M.; Camus, A.; Le Visage, C.; Guicheux, J. Intervertebral disc regeneration: From cell therapy to the development of novel bioinspired endogenous repair strategies. Adv. Drug Deliv. Rev. 2018. [CrossRef] [PubMed] 
2. Iatridis, J.C.; Kang, J.; Kandel, R.; Risbud, M.V. New horizons in spine research: Intervertebral disc repair and regeneration. J. Orthop. Res. 2017, 35, 5-7. [CrossRef] [PubMed]

3. Ahsan, R.; Tajima, N.; Chosa, E.; Sugamata, M.; Sumida, M.; Hamada, M. Biochemical and morphological changes in herniated human intervertebral disc. J. Orthop. Sci. 2001, 6, 510-518. [CrossRef] [PubMed]

4. Buckwalter, J.A. Aging and degeneration of the human intervertebral disc. Spine 1995, 20, 1307-1314. [CrossRef]

5. Ding, F.; Shao, Z.W.; Xiong, L.M. Cell death in intervertebral disc degeneration. Apoptosis 2013, 18, 777-785. [CrossRef] [PubMed]

6. Eskola, P.J.; Lemmelä, S.; Kjaer, P.; Solovieva, S.; Männikkö, M.; Tommerup, N.; Lind-Thomsen, A.; Husgafvel-Pursiainen, K.; Cheung, K.M.; Chan, D.; et al. Genetic association studies in lumbar disc degeneration: A systematic review. PLoS ONE 2012, 7, e49995. [CrossRef]

7. Kepler, C.K.; Ponnappan, R.K.; Tannoury, C.A.; Risbud, M.V.; Anderson, D.G. The molecular basis of intervertebral disc degeneration. Spine J. 2013, 13, 318-330. [CrossRef]

8. Hudson, K.D.; Alimi, M.; Grunert, P.; Hartl, R.; Bonassar, L.J. Recent advances in biological therapies for disc degeneration: Tissue engineering of the annulus fibrosus, nucleus pulposus and whole intervertebral discs. Curr. Opin. Biotechnol. 2013, 24, 872-879. [CrossRef]

9. Cunha, C.; Almeida, C.R.; Almeida, M.I.; Silva, A.M.; Molinos, M.; Lamas, S.; Pereira, C.L.; Teixeira, G.Q.; Monteiro, A.T.; Santos, S.G.; et al. Systemic delivery of bone marrow mesenchymal stem cells for in situ intervertebral disc regeneration. Stem Cells Transl. Med. 2017, 6, 1029-1039. [CrossRef]

10. Di Martino, A.; Vaccaro, A.R.; Lee, J.Y.; Denaro, V.; Lim, M.R. Nucleus pulposus replacement: Basic science and indications for clinical use. Spine 2005, 30, S16-S22. [CrossRef]

11. Fontana, G.; See, E.; Pandit, A. Current trends in biologics delivery to restore intervertebral disc anabolism. Adv. Drug Deliv. Rev. 2015, 84, 146-158. [CrossRef] [PubMed]

12. Guterl, C.C.; See, E.Y.; Blanquer, S.B.; Pandit, A.; Ferguson, S.J.; Benneker, L.M.; Grijpma, D.W.; Sakai, D.; Eglin, D.; Alini, M.; et al. Challenges and strategies in the repair of ruptured annulus fibrosus. Eur. Cell Mater. 2013, 25, 1-21. [CrossRef] [PubMed]

13. Raj, P.P. Intervertebral disc: Anatomy-physiology-pathophysiology-treatment. Pain Pract. 2008, 8, 18-44. [CrossRef] [PubMed]

14. Pattappa, G.; Li, Z.; Peroglio, M.; Wismer, N.; Alini, M.; Grad, S. Diversity of intervertebral disc cells: Phenotype and function. J. Anat. 2012, 221, 480-496. [CrossRef] [PubMed]

15. Walter, B.A.; Torre, O.M.; Laudier, D.; Naidich, T.P.; Hecht, A.C.; Iatridis, J.C. Form and function of the intervertebral disc in health and disease: A morphological and stain comparison study. J. Anat. 2015, 227, 707-716. [CrossRef] [PubMed]

16. Singh, K.; Masuda, K.; Thonar, E.J.; An, H.S.; Cs-Szabo, G. Age-related changes in the extracellular matrix of nucleus pulposus and anulus fibrosus of human intervertebral disc. Spine 2009, 34, 10-16. [CrossRef] [PubMed]

17. Urban, J.; Roberts, S. Degeneration of the intervertebral disc. Arthritis Res. Ther. 2003, 5, 120-130. [CrossRef] [PubMed]

18. Roberts, S.; Evans, H.; Trivedi, J.; Menage, J. Histology and pathology of the human intervertebral disc. J. Bone Jt. Surg. Am. 2006, 88, 10-14.

19. MacGregor, A.J.; Andrew, T.; Sambrook, P.N.; Spector, T.D. Structural, psychological, and genetic influences on low back and neck pain: A study of adult female twins. Arthritis Rheum. 2004, 51, 160-167. [CrossRef]

20. Walker, M.H.; Anderson, D.G. Molecular basis of intervertebral disc degeneration. Spine J. 2004, 4, 158S-166S. [CrossRef] [PubMed]

21. Noble, P.W. Hyaluronan and its catabolic products in tissue injury and repair. Matrix Biol. 2002, 21, 25-29. [CrossRef]

22. Wang, Y.; Yi, X.-D. The influence of artificial nucleus pulposus replacement on stress distribution in the cartilaginous endplate in a 3-dimensional finite element model of the lumbar intervertebral disc. Medicine 2017, 96, e9149. [CrossRef] [PubMed]

23. Freemont, A. The cellular pathobiology of the degenerate intervertebral disc and discogenic back pain. Rheumatology 2009, 48, 5-10. [CrossRef] [PubMed]

24. Vaday, G.G.; Lider, O. Extracellular matrix moieties, cytokines, and enzymes: Dynamic effects on immune cell behavior and inflammation. J. Leukoc. Biol. 2000, 67, 149-159. [CrossRef] [PubMed] 
25. Bao, Q.B.; McCullen, G.M.; Higham, P.A.; Dumbleton, J.H.; Yuan, H.A. The artificial disc: Theory, design and materials. Biomaterials 1996, 17, 1157-1167. [CrossRef]

26. Brinjikji, W.; Luetmer, P.H.; Comstock, B.; Bresnahan, B.W.; Chen, L.E.; Deyo, R.A.; Halabi, S.; Turner, J.A.; Avins, A.L.; James, K.; et al. Systematic literature review of imaging features of spinal degeneration in asymptomatic populations. Am. J. Neuroradiol. 2015, 36, 811-816. [CrossRef]

27. Lim, T.K.Y.; Anderson, K.M.; Hari, P.; Di Falco, M.; Reihsen, T.E.; Wilcox, G.L.; Belani, K.G.; LaBoissiere, S.; Pinto, M.R.; Beebe, D.S.; et al. Evidence for a role of nerve injury in painful intervertebral disc degeneration: A cross-sectional proteomic analysis of human cerebrospinal fluid. J. Pain 2017, 18, 1253-1269. [CrossRef]

28. Masuda, K.; Lotz, J.C. New challenges for intervertebral disc treatment using regenerative medicine. Tissue Eng. Part B Rev. 2010, 16, 147-158. [CrossRef]

29. Bridwell, K.H.; Anderson, P.A.; Boden, S.D.; Vaccaro, A.R.; Wang, J.C. What's new in spine surgery. J. Bone Jt. Surg. Am. 2013, 95, 1144-1150. [CrossRef]

30. Adams, M.A.; Dolan, P. Intervertebral disc degeneration: Evidence for two distinct phenotypes. J. Anat. 2012, 221, 497-506. [CrossRef]

31. Zhang, C.; Berven, S.H.; Fortin, M.; Weber, M.H. Adjacent segment degeneration versus disease after lumbar spine fusion for degenerative pathology: A systematic review with meta-analysis of the literature. Clin. Spine Surg. 2016, 29, 21-29. [CrossRef] [PubMed]

32. Zigler, J.E.; Delamarter, R.B. Five-year results of the prospective, randomized, multicenter, food and drug administration investigational device exemption study of the prodisc-l total disc replacement versus circumferential arthrodesis for the treatment of single-level degenerative disc disease. J. Neurosurg. Spine 2012, 17, 493-501. [PubMed]

33. Ingham, E.; Fisher, J. Biological reactions to wear debris in total joint replacement. Proc. Inst. Mech. Eng. H 2000, 214, 21-37. [CrossRef]

34. Sundfeldt, M.; Carlsson, L.V.; Johansson, C.B.; Thomsen, P.; Gretzer, C. Aseptic loosening, not only a question of wear: A review of different theories. Acta Orthop. 2006, 77, 177-197. [CrossRef] [PubMed]

35. Jiang, L.; Yuan, F.; Yin, X.; Dong, J. Responses and adaptations of intervertebral disc cells to microenvironmental stress: A possible central role of autophagy in the adaptive mechanism. Connect. Tissue Res. 2014, 55, 311-321. [CrossRef] [PubMed]

36. Roughley, P.J. Biology of intervertebral disc aging and degeneration: Involvement of the extracellular matrix. Spine 2004, 29, 2691-2699. [CrossRef]

37. Urban, J.P.; Smith, S.; Fairbank, J.C. Nutrition of the intervertebral disc. Spine 2004, 29, 2700-2709. [CrossRef]

38. Shiri, R.; Karppinen, J.; Leino-Arjas, P.; Solovieva, S.; Viikari-Juntura, E. The association between smoking and low back pain: A meta-analysis. Am. J. Med. 2010, 123, e87-e35. [CrossRef] [PubMed]

39. Schizas, C.; Kulik, G.; Kosmopoulos, V. Disc degeneration: Current surgical options. Eur. Cell Mater. 2010, 20, 306-315. [CrossRef]

40. Lewis, G. Nucleus pulposus replacement and regeneration/repair technologies: Present status and future prospects. J. Biomed. Mater. Res. Part B Appl. Biomater. 2012, 100, 1702-1720. [CrossRef]

41. Bertagnoli, R.; Sabatino, C.T.; Edwards, J.T.; Gontarz, G.A.; Prewett, A.; Parsons, J.R. Mechanical testing of a novel hydrogel nucleus replacement implant. Spine J. 2005, 5, 672-681. [CrossRef] [PubMed]

42. Coric, D.; Mummaneni, P.V. Nucleus replacement technologies. J. Neurosurg. Spine 2008, 8, 115-120. [CrossRef] [PubMed]

43. Yeung, A.T.; Morganstern, R.; Knight, M.; Prewett, A. The feasibility of a novel hydrogel (hpan) intra-discal implant for nucleus augmentation. In Proceedings of the International Conference and Expo on Musculoskeletal Disease and Regeneration, Chicago, IL, USA, 6 May 2016.

44. Durdag, E.; Ayden, O.; Albayrak, S.; Atci, I.B.; Armagan, E. Fragmentation to epidural space: First documented complication of gelstix(tm.). Turk. Neurosurg. 2014, 24, 602-605. [PubMed]

45. Goins, M.L.; Wimberley, D.W.; Yuan, P.S.; Fitzhenry, L.N.; Vaccaro, A.R. Nucleus pulposus replacement: An emerging technology. Spine J. 2005, 5, 317S-324S. [CrossRef] [PubMed]

46. Huang, Y.C.; Hu, Y.; Li, Z.; Luk, K.D.K. Biomaterials for intervertebral disc regeneration: Current status and looming challenges. J. Tissue Eng. Regen. Med. 2018, 12, 2188-2202. [CrossRef] [PubMed]

47. Melrose, J. Strategies in regenerative medicine for intervertebral disc repair using mesenchymal stem cells and bioscaffolds. Regen. Med. 2016, 11, 705-724. [CrossRef] [PubMed] 
48. Van Uden, S.; Silva-Correia, J.; Oliveira, J.M.; Reis, R.L. Current strategies for treatment of intervertebral disc degeneration: Substitution and regeneration possibilities. Biomater. Res. 2017, 21, 22. [CrossRef]

49. Kennon, J.C.; Awad, M.E.; Chutkan, N.; DeVine, J.; Fulzele, S. Current insights on use of growth factors as therapy for intervertebral disc degeneration. Biomol. Concepts 2018, 9, 43-52. [CrossRef]

50. Gullbrand, S.E.; Ashinsky, B.G.; Bonnevie, E.D.; Kim, D.H.; Engiles, J.B.; Smith, L.J.; Elliott, D.M.; Schaer, T.P.; Smith, H.E.; Mauck, R.L. Long-term mechanical function and integration of an implanted tissue-engineered intervertebral disc. Sci. Transl. Med. 2018, 10, eaau0670. [CrossRef]

51. Priyadarshani, P.; Li, Y.; Yao, L. Advances in biological therapy for nucleus pulposus regeneration. Osteoarthr. Cartil. 2016, 24, 206-212. [CrossRef]

52. Buric, J.; Pulidori, M. Long-term reduction in pain and disability after surgery with the interspinous device for intervertebral assisted motion (diam) spinal stabilization system in patients with low back pain: 4-year follow-up from a longitudinal prospective case series. Eur. Spine J. 2011, 20, 1304-1311. [CrossRef] [PubMed]

53. Liu, Y.; Zhou, G.; Cao, Y. Recent progress in cartilage tissue engineering-our experience and future directions. Engineering 2017, 3, 28-35. [CrossRef]

54. Cao, Z.; Dou, C.; Dong, S. Scaffolding biomaterials for cartilage regeneration. J. Nanomater. 2014, $2014,1-8$. [CrossRef]

55. Liu, W.; Cao, Y. Application of scaffold materials in tissue reconstruction in immunocompetent mammals: Our experience and future requirements. Biomaterials 2007, 28, 5078-5086. [CrossRef] [PubMed]

56. Sart, S.; Tsai, A.C.; Li, Y.; Ma, T. Three-dimensional aggregates of mesenchymal stem cells: Cellular mechanisms, biological properties, and applications. Tissue Eng. Part B Rev. 2014, 20, 365-380. [CrossRef] [PubMed]

57. Fujie, H.; Nansai, R.; Ando, W.; Shimomura, K.; Moriguchi, Y.; Hart, D.A.; Nakamura, N. Zone-specific integrated cartilage repair using a scaffold-free tissue engineered construct derived from allogenic synovial mesenchymal stem cells: Biomechanical and histological assessments. J. Biomech. 2015, 48, 4101-4108. [CrossRef] [PubMed]

58. Fei, S.L.; Yu, Y.L.; Tang, C.L.; Lv, F.Z. Effects of tgf- $\beta 1$ and il-1 $\beta$ on expression of adamts enzymes and timp-3 in human intervertebral disc degeneration. Exp. Ther. Med. 2013, 6, 1522-1526.

59. Lee, S.; Moon, C.S.; Sul, D.; Lee, J.; Bae, M.; Hong, Y.; Lee, M.; Choi, S.; Derby, R.; Kim, B.J.; et al. Comparison of growth factor and cytokine expression in patients with degenerated disc disease and herniated nucleus pulposus. Clin. Biochem. 2009, 42, 1504-1511. [CrossRef]

60. Lee, K.I.; Moon, S.H.; Kim, H.; Kwon, U.H.; Kim, H.J.; Park, S.N.; Suh, H.; Lee, H.M.; Kim, H.S.; Chun, H.J.; et al. Tissue engineering of the intervertebral disc with cultured nucleus pulposus cells using atelocollagen scaffold and growth factors. Spine 2012, 37, 452-458. [CrossRef] [PubMed]

61. Gilbertson, L.; Ahn, S.H.; Teng, P.N.; Studer, R.K.; Niyibizi, C.; Kang, J.D. The effects of recombinant human bone morphogenetic protein-2, recombinant human bone morphogenetic protein-12, and adenoviral bone morphogenetic protein-12 on matrix synthesis in human annulus fibrosis and nucleus pulposus cells. Spine J. 2008, 8, 449-456. [CrossRef]

62. Leung, V.; Zhou, L.; Tam, W.; Sun, Y.; Lv, F.; Zhou, G.; Cheung, K. Bone morphogenetic protein-2 and-7 mediate the anabolic function of nucleus pulposus cells with discrete mechanisms. Connect. Tissue Res. 2017, 58, 573-585. [CrossRef] [PubMed]

63. Fei, Q.; Jiang, X.; Chen, T.; Li, J.; Murakami, H.; Tsai, K.; Hutton, W. Changes with age and the effect of recombinant human bmp-2 on proteoglycan and collagen gene expression in rabbit anulus fibrosus cells. Acta Biochim. Et Biophys. Sin. 2006, 38, 773-779. [CrossRef] [PubMed]

64. Kong, M.; Do, D.; Miyazaki, M.; Wei, F.; Yoon, S.; Wang, J. Rabbit model for in vivo study of intervertebral disc degeneration and regeneration. J. Korean Neurosurg. Soc. 2008, 44, 327-333. [CrossRef] [PubMed]

65. Huang, K.; Yan, J.; Hsieh, C.; Chang, M.; Lin, R. The in vivo biological effects of intradiscal recombinant human bone morphogenetic protein-2 on the injured intervertebral disc-An animal experiment. Spine 2007, 32, 1174-1180. [CrossRef] [PubMed]

66. Kawakami, M.; Matsumoto, T.; Hashizume, H.; Kuribayashi, K.; Chubinskaya, S.; Yoshida, M. Osteogenic protein-1 (osteogenic protein-1/bone morphogenetic protein-7) inhibits degeneration and pain-related behavior induced by chronically compressed nucleus pulposus in the rat. Spine 2005, 30, 1933-1939. [CrossRef] [PubMed] 
67. Wei, A.; Brisby, H.; Chung, S.A.; Diwan, A.D. Bone morphogenetic protein-7 protects human intervertebral disc cells in vitro from apoptosis. Spine J. 2008, 8, 466-474. [CrossRef] [PubMed]

68. Takegami, K.; Thonar, E.; An, H.; Kamada, H.; Masuda, K. Osteogenic protein-1 enhances matrix replenishment by intervertebral disc cells previously exposed to interleukin-1. Spine 2002, 27, 1318-1324. [CrossRef]

69. An, H.; Takegami, K.; Kamada, H.; Nguyen, C.; Thonar, E.; Singh, K.; Andersson, G.; Masuda, K. Intradiscal administration of osteogenic protein-1 increases intervertebral disc height and proteoglycan content in the nucleus pulposus in normal adolescent rabbits. Spine 2005, 30, 25-31. [CrossRef]

70. Masuda, K.; Imai, Y.; Okuma, M.; Muehleman, C.; Nakagawa, K.; Akeda, K.; Thonar, E.; Andersson, G.; An, H. Osteogenic protein-1 injection into a degenerated disc induces the restoration of disc height and structural changes in the rabbit anular puncture model. Spine 2006, 31, 742-754. [CrossRef]

71. Chubinskaya, S.; Kawakami, M.; Rappoport, L.; Matsumoto, T.; Migita, N.; Rueger, D. Anti-catabolic effect of op-1 in chronically compressed intervertebral discs. J. Orthop. Res. 2007, 25, 517-530. [CrossRef]

72. Willems, N.; Bach, F.C.; Plomp, S.G.M.; van Rijen, M.H.P.; Wolfswinkel, J.; Grinwis, G.C.M.; Bos, C.; Strijkers, G.J.; Dhert, W.J.A.; Meij, B.P. Intradiscal application of rhbmp-7 does not induce regeneration in a canine model of spontaneous intervertebral disc degeneration. Arthritis Res. Ther. 2015, 17, 137. [CrossRef] [PubMed]

73. Van Dijk, B.G.M.; Potier, E.; van Dijk, M.; Creemers, L.B.; Ito, K. Osteogenic protein 1 does not stimulate a regenerative effect in cultured human degenerated nucleus pulposus tissue. J. Tissue Eng. Regen. Med. 2017, 11, 2127-2135. [CrossRef] [PubMed]

74. Chujo, T.; An, H.; Akeda, K.; Miyamoto, K.; Muehleman, C.; Attawia, M.; Andersson, G.; Masuda, K. Effects of growth differentiation factor- 5 on the intervertebral disc - in vitro bovine study and in vivo rabbit disc degeneration model study. Spine 2006, 31, 2909-2917. [CrossRef] [PubMed]

75. Feng, C.; Liu, H.; Yang, Y.; Huang, B.; Zhou, Y. Growth and differentiation factor-5 contributes to the structural and functional maintenance of the intervertebral disc. Cell. Physiol. Biochem. 2015, 35, 1-16. [CrossRef] [PubMed]

76. Bach, F.C.; Willems, N.; Penning, L.C.; Ito, K.; Meij, B.P.; Tryfonidou, M.A. Potential regenerative treatment strategies for intervertebral disc degeneration in dogs. BMC Vet. Res. 2014, 10, 3. [CrossRef] [PubMed]

77. Walsh, A.J.; Bradford, D.S.; Lotz, J.C. In vivo growth factor treatment of degenerated intervertebral discs. Spine 2004, 29, 156-163. [CrossRef] [PubMed]

78. Kim, J.; Ellman, M.; An, H.; van Wijnen, A.; Borgia, J.; Im, H. Insulin-like growth factor 1 synergizes with bone morphogenetic protein 7-mediated anabolism in bovine intervertebral disc cells. Arthritis Rheum. 2010, 62, 3706-3715. [CrossRef]

79. Pratsinis, H.; Kletsas, D. Organotypic cultures of intervertebral disc cells: Responses to growth factors and signaling pathways involved. BioMed Res. Int. 2015, 2015, 427138. [CrossRef]

80. Jiang, C.; Li, D.P.; Zhang, Z.J.; Shu, H.M.; Hu, L.; Li, Z.N.; Huang, Y.H. Effect of basic fibroblast growth factor and transforming growth factor- $\beta 1$ combined with bone marrow mesenchymal stem cells on the repair of degenerated intervertebral discs in rat models. Chin. Acad. Med. Sci. 2015, 37, 456-465.

81. Zhu, Y.; Yuan, M.; Meng, H.Y.; Wang, A.Y.; Guo, Q.Y.; Wang, Y.; Peng, J. Basic science and clinical application of platelet-rich plasma for cartilage defects and osteoarthritis: A review. Osteoarthr. Cartil. 2013, 21, 1627-1637. [CrossRef]

82. Wang, S.Z.; Chang, Q.; Lu, J.; Wang, C. Growth factors and platelet-rich plasma: Promising biological strategies for early intervertebral disc degeneration. Int. Orthop. 2015, 39, 927-934. [CrossRef] [PubMed]

83. Sakai, D.; Grad, S. Advancing the cellular and molecular therapy for intervertebral disc disease. Adv. Drug Deliv. Rev. 2015, 84, 159-171. [CrossRef] [PubMed]

84. Masuda, K.; An, H.S. Prevention of disc degeneration with growth factors. Eur. Spine J. 2006, 15, S422-S432. [CrossRef] [PubMed]

85. Wang, Y.; Wei, L.; He, D.; Zeng, L.; Wei, X. Nutrition and degeneration of articular cartilage. Knee Surg. Sports Traumatol. Arthrosc. 2013, 21, 1751-1762. [CrossRef] [PubMed]

86. Benneker, L.M.; Andersson, G.; Iatridis, J.C.; Sakai, D.; Härtl, R.; Ito, K.; Grad, S. Cell therapy for intervertebral disc repair: Advancing cell therapy from bench to clinics. Eur. Cell Mater. 2014, 27, 5-11. [CrossRef] 
87. Abbott, R.D.; Purmessur, D.; Monsey, R.D.; Iatridis, J.C. Regenerative potential of tgfbeta3 + dex and notochordal cell conditioned media on degenerated human intervertebral disc cells. J. Orthop. Res. 2012, 30, 482-488. [CrossRef]

88. Coric, D.; Pettine, K.; Sumich, A.; Boltes, M.O. Prospective study of disc repair with allogeneic chondrocytes presented at the 2012 joint spine section meeting. J. Neurosurg. Spine 2013, 18, 85-95. [CrossRef]

89. Peroglio, M.; Douma, L.; Caprez, T.; Janki, M.; Benneker, L.; Alini, M.; Grad, S. Intervertebral disc response to stem cell treatment is conditioned by disc state and cell carrier: An ex vivo study. J. Orthop. Transl. 2017, 9, 43-51. [CrossRef]

90. Watanabe, T.; Sakai, D.; Yamamoto, Y.; Iwashina, T.; Serigano, K.; Tamura, F.; Mochida, J. Human nucleus pulposus cells significantly enhanced biological properties in a coculture system with direct cell-to-cell contact with autologous mesenchymal stem cells. J. Orthop. Res. 2010, 28, 623-630. [CrossRef]

91. Zhou, X.; Wang, J.; Fang, W.; Tao, Y.; Zhao, T.; Xia, K.; Liang, C.; Hua, J.; Li, F.; Chen, Q. Genipin cross-linked type ii collagen/chondroitin sulfate composite hydrogel-like cell delivery system induces differentiation of adipose-derived stem cells and regenerates degenerated nucleus pulposus. Acta Biomater. 2018, 71, 496-509. [CrossRef]

92. Risbud, M.V.; Albert, T.J.; Guttapalli, A.; Vresilovic, E.J.; Hillibrand, A.S.; Vaccaro, A.R.; Shapiro, I.M. Differentiation of mesenchymal stem cells towards a nucleus pulposus-like phenotype in vitro: Implications for cell-based transplantation therapy. Spine 2004, 29, 2627-2632. [CrossRef] [PubMed]

93. Meisel, H.J.; Siodla, V.; Ganey, T.; Minkus, Y.; Hutton, W.C.; Alasevic, O.J. Clinical experience in cell-based therapeutics: Disc chondrocyte transplantation a treatment for degenerated or damaged intervertebral disc. Biomol. Eng. 2007, 24, 5-21. [CrossRef] [PubMed]

94. Vedicherla, S.; Buckley, C.T. Cell-based therapies for intervertebral disc and cartilage regeneration-Current concepts, parallels, and perspectives. J. Orthop. Res. 2017, 35, 8-22. [CrossRef] [PubMed]

95. Sakai, D.; Schol, J. Cell therapy for intervertebral disc repair: Clinical perspective. J. Orthop. Transl. 2017, 9, 8-18. [CrossRef]

96. Chakravarthy, K.; Chen, Y.; He, C.; Christo, P.J. Stem cell therapy for chronic pain management: Review of uses, advances, and adverse effects. Pain Physician 2017, 20, 293-305. [PubMed]

97. Sakai, D.; Mochida, J.; Iwashina, T.; Watanabe, T.; Nakai, T.; Ando, K.; Hotta, T. Differentiation of mesenchymal stem cells transplanted to a rabbit degenerative disc model: Potential and limitations for stem cell therapy in disc regeneration. Spine 2005, 30, 2379-2387. [CrossRef] [PubMed]

98. Zhang, Y.; Drapeau, S.; An, H.S.; Thonar, E.J.M.A.; Anderson, D.G. Transplantation of goat bone marrow stromal cells to the degenerating intervertebral disc in a goat disc-injury model. Spine 2011, 36, 372. [CrossRef]

99. Ganey, T.; Hutton, W.C.; Moseley, T.; Hedrick, M.; Meisel, H.-J. Intervertebral disc repair using adipose tissue-derived stem and regenerative cells: Experiments in a canine model. Spine 2009, 34, 2297-2304. [CrossRef]

100. Chen, X.; Zhu, L.; Wu, G.; Liang, Z.; Yang, L.; Du, Z. A comparison between nucleus pulposus-derived stem cell transplantation and nucleus pulposus cell transplantation for the treatment of intervertebral disc degeneration in a rabbit model. Int. J. Surg. 2016, 28, 77-82. [CrossRef]

101. Murdoch, A.D.; Grady, L.M.; Ablett, M.P.; Katopodi, T.; Meadows, R.S.; Hardingham, T.E. Chondrogenic differentiation of human bone marrow stem cells in transwell cultures: Generation of scaffold-free cartilage. Stem Cells 2007, 25, 2786-2796. [CrossRef]

102. Fernandez-Moure, J.; Moore, C.A.; Kim, K.; Karim, A.; Smith, K.; Barbosa, Z.; Van Eps, J.; Rameshwar, P.; Weiner, B. Novel therapeutic strategies for degenerative disc disease: Review of cell biology and intervertebral disc cell therapy. SAGE Open Med. 2018, 6, 2050312118761674. [CrossRef] [PubMed]

103. Arkesteijn, I.T.M.; Potier, E.; Ito, K. The regenerative potential of notochordal cells in a nucleus pulposus explant. Glob. Spine J. 2017, 7, 14-20. [CrossRef] [PubMed]

104. Gantenbein-Ritter, B.; Chan, S.C. The evolutionary importance of cell ratio between notochordal and nucleus pulposus cells: An experimental 3-d co-culture study. Eur. Spine J. 2012, 21 (Suppl. 6), S819-S825. [CrossRef] [PubMed]

105. Matta, A.; Karim, M.Z.; Isenman, D.E.; Erwin, W.M. Molecular therapy for degenerative disc disease: Clues from secretome analysis of the notochordal cell-rich nucleus pulposus. Sci. Rep. 2017, 7, 45623. [CrossRef] [PubMed] 
106. Risbud, M.V.; Shapiro, I.M. Notochordal cells in the adult intervertebral disc: New perspective on an old question. Crit. Rev. Eukaryot. Gene Expr. 2011, 21, 29-41. [CrossRef] [PubMed]

107. Bach, F.C.; de Vries, S.A.; Krouwels, A.; Creemers, L.B.; Ito, K.; Meij, B.P.; Tryfonidou, M.A. The species-specific regenerative effects of notochordal cell-conditioned medium on chondrocyte-like cells derived from degenerated human intervertebral discs. Eur. Cell Mater. 2015, 30, 132-147. [CrossRef] [PubMed]

108. Serigano, K.; Sakai, D.; Hiyama, A.; Tamura, F.; Tanaka, M.; Mochida, J. Effect of cell number on mesenchymal stem cell transplantation in a canine disc degeneration model. J. Orthop. Res. 2010, 28, 1267-1275. [CrossRef] [PubMed]

109. Peppas, N.A.; Hilt, J.Z.; Khademhosseini, A.; Langer, R. Hydrogels in biology and medicine: From molecular principles to bionanotechnology. Adv. Mater. 2006, 18, 1345-1360. [CrossRef]

110. Chuang, E.-Y.; Chiang, C.-W.; Wong, P.-C.; Chen, C.-H. Hydrogels for the application of articular cartilage tissue engineering: A review of hydrogels. Adv. Mater. Sci. Eng. 2018, 2018, 1-13. [CrossRef]

111. Yang, J.; Zhang, Y.S.; Yue, K.; Khademhosseini, A. Cell-laden hydrogels for osteochondral and cartilage tissue engineering. Acta Biomater. 2017, 57, 1-25. [CrossRef]

112. Li, Z.; Lang, G.; Karfeld-Sulzer, L.S.; Mader, K.T.; Richards, R.G.; Weber, F.E.; Sammon, C.; Sacks, H.; Yayon, A.; Alini, M.; et al. Heterodimeric bmp-2/7 for nucleus pulposus regeneration-in vitro and ex vivo studies. J. Orthop. Res. 2017, 35, 51-60. [CrossRef]

113. Nesti, L.J.; Li, W.J.; Shanti, R.M.; Jiang, Y.J.; Jackson, W.; Freedman, B.A.; Kuklo, T.R.; Giuliani, J.R.; Tuan, R.S. Intervertebral disc tissue engineering using a novel hyaluronic acid-nanofibrous scaffold (hanfs) amalgam. Tissue Eng. Part A 2008, 14, 1527-1537. [CrossRef] [PubMed]

114. Frith, J.E.; Cameron, A.R.; Menzies, D.J.; Ghosh, P.; Whitehead, D.L.; Gronthos, S.; Zannettino, A.C.W.; Cooper-White, J.J. An injectable hydrogel incorporating mesenchymal precursor cells and pentosan polysulphate for intervertebral disc regeneration. Biomaterials 2013, 34, 9430-9440. [CrossRef] [PubMed]

115. Yan, J.; Yang, S.; Sun, H.; Guo, D.; Wu, B.; Ji, F.; Zhou, D. Effects of releasing recombinant human growth and differentiation factor-5 from poly(lactic-co-glycolic acid) microspheres for repair of the rat degenerated intervertebral disc. J. Biomater. Appl. 2014, 29, 72-80. [CrossRef] [PubMed]

116. Moriguchi, Y.; Mojica-Santiago, J.; Grunert, P.; Pennicooke, B.; Berlin, C.; Khair, T.; Navarro-Ramirez, R.; Arbona, R.J.R.; Nguyen, J.; Härtl, R. Total disc replacement using tissue-engineered intervertebral discs in the canine cervical spine. PLOS ONE 2017, 12, e0185716. [CrossRef] [PubMed]

117. D'Este, M.; Eglin, D.; Alini, M. Lessons to be learned and future directions for intervertebral disc biomaterials. Acta Biomater. 2018, 78, 13-22. [CrossRef]

118. Sun, Y.; Leung, V.Y.; Cheung, K.M. Clinical trials of intervertebral disc regeneration: Current status and future developments. Int. Orthop. 2019, 43, 1003-1010. [CrossRef] 